\title{
Quasi Solid-State Dye-Sensitized Solar Cell Incorporating Highly Conducting Polythiophene-Coated Carbon Nanotube Composites in Ionic Liquid
}

\author{
Mohammad Rezaul Karim, ${ }^{1}$ Ashraful Islam, ${ }^{1,2}$ Surya Prakash Singh, ${ }^{2}$ and Liyuan Han ${ }^{2}$ \\ ${ }^{1}$ Center of Excellence for Research in Engineering Materials (CEREM), College of Engineering, King Saud University, \\ Riyadh 11421, Saudi Arabia \\ ${ }^{2}$ Photovoltaic Materials Unit, National Institute for Materials Science (NIMS), 1-2-1 Sengen, Tsukuba, Ibaraki 305-0047, Japan
}

Correspondence should be addressed to Mohammad Rezaul Karim, mkarim@ksu.edu.sa

and Ashraful Islam, islam.ashraful@nims.go.jp

Received 30 April 2011; Accepted 13 June 2011

Academic Editor: Ahmed El-Shafei

Copyright ( 92011 Mohammad Rezaul Karim et al. This is an open access article distributed under the Creative Commons Attribution License, which permits unrestricted use, distribution, and reproduction in any medium, provided the original work is properly cited.

Conducting polythiophene (PTh) composites with the host filler multiwalled carbon nanotube (MWNT) have been used, for the first time, in the dye-sensitized solar cells (DSCs). A quasi solid-state DSCs with the hybrid MWNT-PTh composites, an ionic liquid of 1-methyl-3-propyl imidazolium iodide (PMII), was placed between the dye-sensitized porous $\mathrm{TiO}_{2}$ and the Pt counter electrode without adding iodine and higher cell efficiency $(4.76 \%)$ was achieved, as compared to that containing bare PMII (0.29\%). The MWNT-PTh nanoparticles are exploited as the extended electron transfer materials and serve simultaneously as catalyst for the electrochemical reduction of $\mathrm{I}_{3}^{-}$.

\section{Introduction}

Dye-sensitized solar cells (DSCs) have attracted significant attention as promising solar-to-electricity power conversion devices because of their higher energy conversion and potential for low-cost production [1-6]. In general, DSCs comprise an electrode consisting of nanocrystalline titanium dioxide $\left(\mathrm{TiO}_{2}\right)$ films modified with a dye, a platinum counterelectrode, and an electrolyte solution in between the electrodes. Photoexcitation of the dye results in the injection of an electron into the conduction band of the oxide. The original state of the dye is subsequently restored by electron donation from a redox system, such as the iodide/triiodide $\left(\mathrm{I}^{-} / \mathrm{I}_{3}{ }^{-}\right)$couple. At the present, DSCs are mainly constructed by using liquid electrolyte as a charge transport material. The charge transport in these liquid electrolytes is typically achieved by using $\mathrm{I}^{-} / \mathrm{I}_{3}{ }^{-}$redox reaction in electrolyte solution. Therefore, long-term durability of DSCs is limited by leakage and the volatilization of organic solvent-based electrolytes. Numerous investigations have been conferred to overcome this drawback, replacing the liquid electrolyte by organic and inorganic hole transport materials [7-9], polymer and gel electrolytes [10-14], and nanocomposite ionic liquid (IL) electrolytes [15-20] resulting in solid-state and quasi solid-state DSCs. Imperfect pour filling of the dyecoated nanocrystalline $\mathrm{TiO}_{2}$ film with organic and inorganic hole transport materials results in a poor device efficiency. Moreover, the ionic conductivity for the majority of the amorphous polymer electrolytes is too low $\left(<10^{-5} \mathrm{~S} \mathrm{~cm}^{-1}\right)$, limiting the device efficiency. Although nanocomposite IL electrolyte can reduce leakages, it is not satisfactory, because of the high concentration of corrosive and volatile iodine present in the electrolyte. The introduction of $\mathrm{I}_{2}$ into the electrolytes could increase the conductivity of the electrolyte via a Grotthuss-type charge carrier exchange transfer mechanism. However, the increasing content of $I_{2}$ (or $\mathrm{I}_{3}^{-}$) leads to enhanced light absorption even in the visible range by the electrolyte. The increased absorption of visible light by the electrolyte, the enhanced dark current, and the reduced ionic conductivity of the electrolyte contribute to 


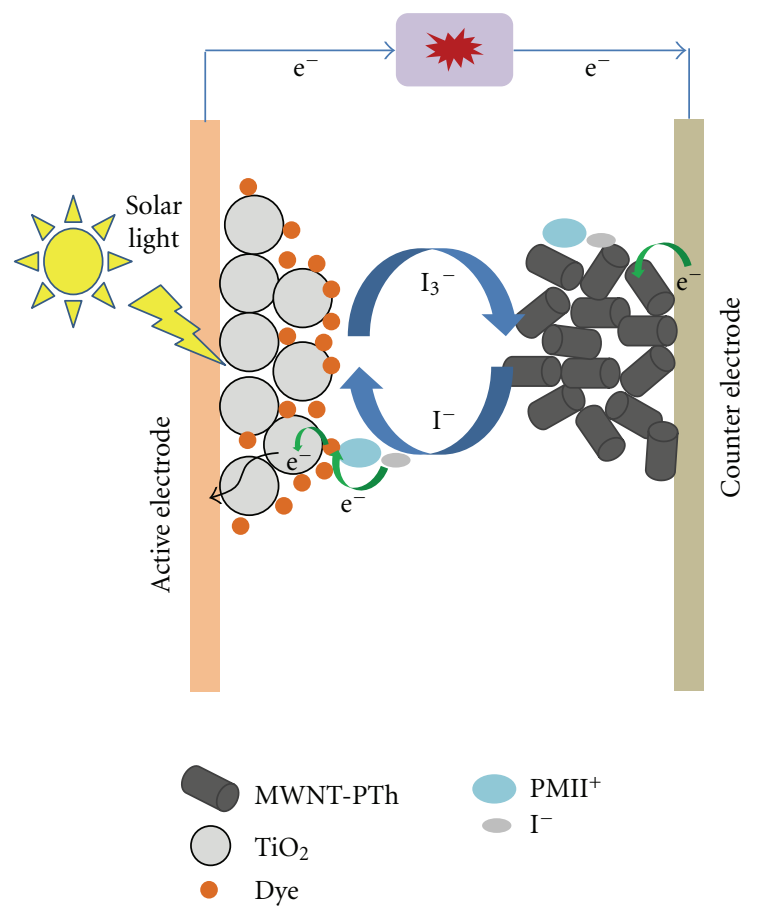

Scheme 1: Schematic design of the charge transport processes in typical quasi solid-state DSCs with an electrolyte containing the MWNTPTh composites and IL.

the performance variation of the corresponding DSCs with increasing $\mathrm{I}_{2}$ concentration.

Conducting polymer-coated carbon nanotube composites are extremely good conducting hybrid materials, which are often used in organic field effect transistor, solar cells, sensors, electrochromic devices, and light emitting diodes [21-24]. Lee and coworkers reported iodine-free quasi solid-state DSCs, containing a conducting polymer loaded carbon black and an ionic liquid, which exhibited a power conversion efficiency of 5.8\% [25]. Recently, Lee et al. further reported an efficient solid-state DSC using a hybrid carbon nanotubes-binary ionic liquid containing1ethyl-3-methylimidazolium iodide (EMII) and 1-methyl-3propylimidazolium iodine (PMII), without the addition of iodine and TBP [26]. Besides, Wang et al. and Ikeda et al. have reported separately a solid-state electrolyte without the incorporation of volatile iodine and achieved high device efficiency [27, 28].

In our earlier work, we reported highly conducting cablelike PTh-MWNT composites, composed of conducting polythiophene (PTh) with the host filler multiwalled carbon nanotube (MWNT), synthesized by the gamma-radiationinduced in situ chemical polymerization method [29]. In this study, core-shell MWNT-PTh composites were added to ionic liquid to form the extended electron transfer surface (Scheme 1) from the counterelectrode's surface to the bulk electrolyte, in order to facilitate electron transfer and, thereby, decrease the dark current from the working electrode to the electrolyte. For the first time, MWNT-PTh composites have been used in DSSC, and the effect of MWNT-PTh composites addition in the solvent-free ionic liquid electrolyte without the incorporation of iodine was studied.

\section{Experimental}

2.1. Materials. The following chemicals were purchased and used without further purification: iodine $\left(\mathrm{I}_{2}\right.$, from Merck), 1-methyl-3-propyl-imidazoliumiodide (MPII, from Merck), tert-butyl alcohol (Fluka), acetonitrile (ACN, 99.99\%, Aldrich), anhydrous iron (III) chloride ( $\mathrm{FeCl}_{3}$,Aldrich), and chloroform $\left(\mathrm{CHCl}_{3}\right.$, Aldrich). Thiophene monomer (99+\%, Aldrich) was distilled under a reduced pressure and kept below $0^{\circ} \mathrm{C}$ prior to use. MWNT ( $>95$ vol. grade, produced by the CVD method; diameter: $10 \sim 20 \mathrm{~nm}$, length: $10 \sim$ $50 \mu \mathrm{m}$ ) was supplied by Iljin Nanotech Co., Ltd., Republic of Korea.

2.2. Composite Electrolyte. The conducting MWNT-PTh hybrid composites were synthesized as per our reported work [29]. The instruments used for the characterization of MWNT-PTh hybrid composites included a field-emission scanning electron microscope (FE-SEM) (Hitachi Model S-4300) and a transmission electron microscope (TEM) (Philips model CM 200) with an Acc. Voltage of $200 \mathrm{kv}$. The room-temperature conductivity of the pressed pellets was measured by the four-point probe method using a Jandel engineering instrument, Model CMT-SR1060N. The composite electrolyte was prepared by mixing the solid powder of MWNT-PTh, PMII, and ACN in a weight ratio of $1: 7: 7$. $\mathrm{ACN}$ was added to the composite to improve the mixing, and was removed on a hot plate at a temperature of $90^{\circ} \mathrm{C}$. 
2.3. Fabrication of Dye-Sensitized Solar Cell. Nanocrystalline $\mathrm{TiO}_{2}$ photoelectrodes of $15 \mu \mathrm{m}$ thickness (area: $0.25 \mathrm{~cm}^{2}$ ) were prepared on conducting glass using a variation of a previously reported method [30]. Fluorine-doped tin oxidecoated glass electrodes (Nippon Sheet Glass Co., Japan) with a sheet resistance of $8-10 \mathrm{ohm}^{-2}$ and an optical transmission of greater than $80 \%$ in the visible range were used. Anatase $\mathrm{TiO}_{2}$ colloid pastes (particle size $\sim 25 \mathrm{~nm}$ and $\sim 400 \mathrm{~nm}$ ) were obtained from commercial sources (Solaronix). The nanocrystalline $\mathrm{TiO}_{2}$ thin films of approximately $15 \mu \mathrm{m}$ thickness were deposited onto the conducting glass by screen printing. The film was sintered at $500^{\circ} \mathrm{C}$ for $1 \mathrm{~h}$. The film thickness was measured with a Surfcom 1400 A surface profiler (Tokyo Seimitsu Co. Ltd.). The electrodes were impregnated with a $0.05 \mathrm{M}$ titanium tetrachloride solution and sintered at $500^{\circ} \mathrm{C}$. A dye solution of $3 \times$ $10^{-4} \mathrm{M} \mathrm{N719}$ was prepared in $1: 1$ acetonitrile and tert-butyl alcohol solvents. Deoxycholic acid $(20 \mathrm{mM})$ was added to the dye solution as a coadsorbent to prevent aggregation of the dye molecules $[31,32]$. The electrodes were immersed in the N719 solution and then kept at $25^{\circ} \mathrm{C}$ for $20 \mathrm{~h}$ to adsorb the dye onto the $\mathrm{TiO}_{2}$ surface. Photovoltaic measurements were performed in a two-electrode sandwich cell configuration. The dye-deposited $\mathrm{TiO}_{2}$ film and a platinum-coated conducting glass were used as the working electrode and the counterelectrode, respectively. A $30 \mu \mathrm{m}$ thick surlyn spacer was put on the dye-deposited $\mathrm{TiO}_{2}$ electrode and attached by heating. The MWNT-PTh/MPII hybrid composite electrolyte was then put onto the dyesensitized $\mathrm{TiO}_{2}$ film at $85^{\circ} \mathrm{C}$ to ensure that the PMII can penetrate well into the porous structure and remove the residual $\mathrm{ACN}$. The dye-deposited $\mathrm{TiO}_{2}$ electrode with the MWNT-PTh/MPII hybrid composite electrolytes was assembled with a platinum-coated conducting glass electrode and sealed by heating the polymer frame. The electrolytes used for liquid cell were composed of $0.6 \mathrm{M}$ dimethylpropylimidazolium iodide (DMPII), $0.05 \mathrm{M} \mathrm{I}_{2}$, and $0.1 \mathrm{M} \mathrm{LiI}$ in acetonitrile.

2.4. Photovoltaic Characterization. The working electrode was illuminated through a conducting glass. The currentvoltage characteristics were measured using a solar simulator (AM-1.5, $100 \mathrm{~mW} / \mathrm{cm}^{2}$, WXS-155S-10: Wacom Denso Co., Japan). Monochromatic incident photon-to-current conversion efficiency (IPCE) for the solar cell, plotted as a function of excitation wavelength, was recorded on a CEP-2000 system (Bunkoh-Keiki Co., Ltd.). Incident photon-to-current conversion efficiency (IPCE) at each incident wavelength was calculated from (1), where $I_{\mathrm{sc}}$ is the photocurrent density at short circuit in $\mathrm{mA} \mathrm{cm}^{-2}$ under monochromatic irradiation, $q$ is the elementary charge, $i$ is the wavelength of incident radiation in $\mathrm{nm}$, and $P_{0}$ is the incident radiative flux in $\mathrm{W} \mathrm{m} \mathrm{m}^{-2}$ :

$$
\operatorname{IPCE}(\lambda)=1240\left(\frac{I_{\mathrm{sc}}}{q \lambda P 0}\right)
$$

\section{Results and Discussion}

Room temperature ionic liquids have several qualities as compared with other choices since they have negligible volatility, high thermal stability, a wide electrochemical potential window, and satisfactory ionic conductivity [33, 34]. Ionic liquids have limited ion diffusion because of its high viscosity. The conductivity of ionic liquid electrolytes is further improved by increasing iodine concentration resulting in a polyiodide formation thus facilitating electronexchange-type conductivity [35]. Increasing of iodine concentration is, however, limited by strong visible light absorption by iodine itself. Therefore, iodide ionic liquids in combination with moderately high iodine concentration only make a satisfactory electrolyte for DSCs. Moreover, it was reported that the carbon material in the iodinefree composite electrolyte serves simultaneously as a charge transporter in the electrolyte and as a catalyst for electrochemical reduction of $\mathrm{I}_{3}{ }^{-}$ions [25]. The iodide anion-based IL can provide sufficient $\mathrm{I}^{-}$for the regeneration of oxidized dye under illumination; $\mathrm{I}^{-}$in turn oxidizes to $\mathrm{I}_{3}{ }^{-}$, which can be reduced back to $\mathrm{I}^{-}$at the carbon material.

A main component of DSCs is the electrolyte that fills the space between the dye-coated porous nanocrystalline $\mathrm{TiO}_{2}$ electrode and the counterelectrode. In the vast majority of cases the electrolyte contains $\mathrm{I}^{-} / \mathrm{I}_{3}{ }^{-}$redox couple. In general, iodide salt and iodine are the source of the $\mathrm{I}^{-} / \mathrm{I}_{3}^{-}$redox couple. In the electrolyte, $\mathrm{I}_{2}$ exists in the form of polyiodides such as $\mathrm{I}_{3}^{-}$or $\mathrm{I}_{5}^{-}$(2). Photoexcitation of the dye results in the injection of an electron into the conduction band of the $\mathrm{TiO}_{2}$. The oxidized state of the dye $\left(\right.$ dye $\left.^{+}\right)$should be regenerated efficiently by electron donation from $\mathrm{I}^{-}(3)$. The efficient regeneration of oxidized dye is crucial for obtaining good electron collection yields and a high cycle life of the sensitizer. Meanwhile, the electrons accumulated at the counterelectrode by the external circuit will lead to concentration over potentials for the electrolyte at the counterelectrode and loss of energy of the DSCs if the electrons are not transferred by $\mathrm{I}_{3}{ }^{-}$efficiently (4). Apart from recapture by the oxidized dye, the electrons can be lost to the electrolyte by reaction with the $\mathrm{I}_{3}^{-}$(5). Therefore an efficient transport of iodide and triiodide in the electrolyte is necessary for good performance of the DSCs. Meanwhile, the increase of the $\mathrm{I}_{3}^{-}$concentration in the electrolyte results in an increasing dark current of the DSCs and thus decreases the device performance:

$$
\begin{gathered}
\mathrm{I}^{-}+\mathrm{I}_{2} \longrightarrow \mathrm{I}_{3}^{-}+\mathrm{I}_{2} \longrightarrow \mathrm{I}_{5}^{-} \text {(electrolyte solution) } \\
3 \mathrm{I}^{-}+2 \text { dye }^{+} \longrightarrow \mathrm{I}_{3}{ }^{-}+2 \text { dye }\left(\mathrm{TiO}_{2} \text { electrode }\right) \\
\mathrm{I}_{3}{ }^{-}+2 \mathrm{e}^{-} \longrightarrow 3 \mathrm{I}^{-}(\text {counterelectrode }) \\
\mathrm{I}_{3}{ }^{-}+2 \mathrm{e}^{-} \mathrm{cb}\left(\mathrm{TiO}_{2} \text { electrode }\right) \longrightarrow 3 \mathrm{I}^{-}
\end{gathered}
$$

Conducting polymer-coated carbon nanotubes are notable materials, which are being widely studied because of their extraordinary electronic and mechanical properties. Considering these aspects, incombustible and nonvolatile PMII and MWNT-PTh composites, were incorporated into 


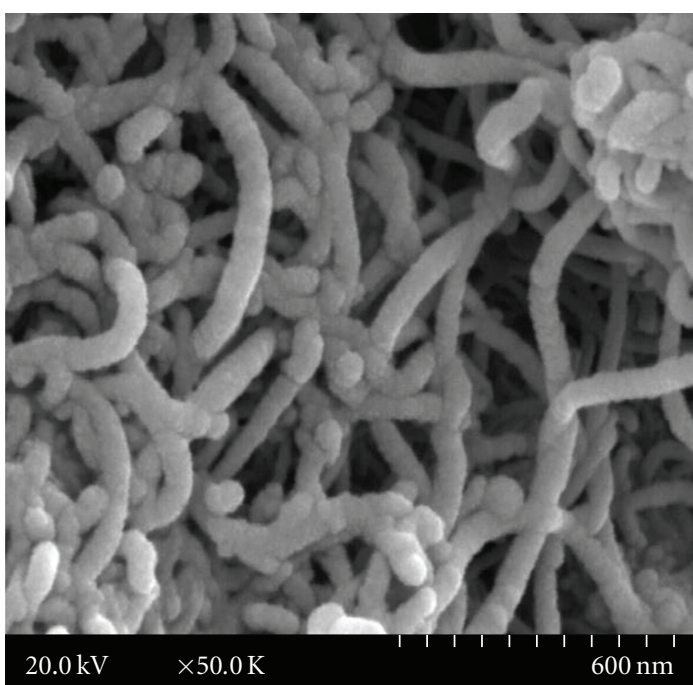

(a)

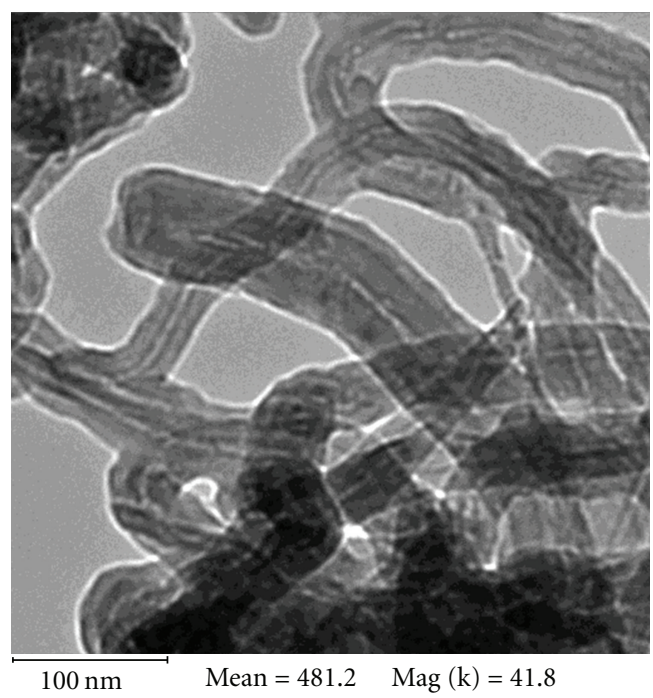

(b)

FIgure 1: (a) FE-SEM and (b) TEM images of MWNT-PTh composites.

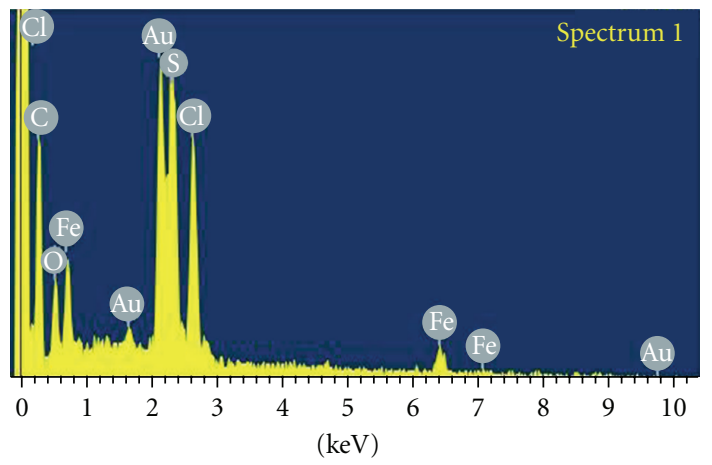

\begin{tabular}{|c|c|c|}
\hline Element & Weight (\%) & Atomic (\%) \\
\hline C K & 24.33 & 58.78 \\
\hline $\mathrm{OK}$ & 4.5 & 8.17 \\
\hline S K & 12.99 & 11.75 \\
\hline $\mathrm{Cl} \mathrm{K}$ & 11.11 & 9.1 \\
\hline Fe L & 14.18 & 7.36 \\
\hline $\mathrm{Au} \mathrm{M}$ & 32.88 & 4.84 \\
\hline Totals & 100 & \\
\hline
\end{tabular}

Full scale 264 cts cursor: 0.000

FIgURE 2: Representative EDS analysis data of MWNT-PTh composites.

DSCs for this study (Scheme 1). The presence of redox-active PMII ionic liquid fills the nanoporous $\mathrm{TiO}_{2} /$ dye interface, where no space is available for MWNT-PTh composites to occupy. It is expected that this IL would allow perfect contact at the interface between the dye-coated porous $\mathrm{TiO}_{2}$ and the conducting polymer-coated carbon material [19], that is, MWNT-PTh composites.

A typical morphology of MWNT-PTh composites synthesized by the radiolysis polymerization method was investigated using scanning electron microscopes (Figure 1). In Figure 1(a), the FE-SEM image shows a uniform view of the MWNT-PTh composites. The tubular morphology of the MWNT-PTh composites was also imaged by the TEM, as shown in Figure 1(b). Structural characterizations showed that there was clear indication of interfacial entrapment between the PTh and MWNT; the conducting polymer is coated on the surface of the carbon nanotube. Here, the tubular inner part (core) is mainly the compound of MWNT and the outer coated surface (shell) is conducting polythiophene with variable thicknesses (20-50 nm diameters), and their external surfaces are not smooth.

Figure 2 shows the energy dispersive spectroscopy (EDS) analysis of MWNT-PTh composites (data are given in the table). The atomic percents of the $\mathrm{C}$ and $\mathrm{S}$ are 58.78 and 11.75 , respectively, for MWNT-PTh composites which reveal that carbon nanotube and polythiophene are both present in the sample. In general, electrical conductivity may be taken as a function of the conjugation length of the polymer and the amount of active dopant present in the polymer, as the number of charge carriers depends upon the extent of the dopant concentration, provided that other factors remain unchanged. A powder sample of $0.02 \mathrm{~g}$ was loaded and pressed into a pellet $1.2 \mathrm{~cm}$ in diameter and a pressure of $170 \mathrm{~atm}$ by a manual hydraulic press for $10 \mathrm{~min}$. Then, the electrical conductivity of the pellets was measured by a standard four-point probe method, connected to a Keithley 
TABle 1: Photovoltaic properties of the DSCs with MWNT-PTh/PMII composite electrolyte and with bare PMII electrolyte using Pt/ITO and bare ITO as counterelectrode. ${ }^{\mathrm{a}}$

\begin{tabular}{|c|c|c|c|c|c|}
\hline Electrolyte & Counterelectrode & $J_{\mathrm{sc}}\left(\mathrm{mA} \mathrm{cm}^{-2}\right)$ & $V_{\mathrm{oc}}(\mathrm{V})$ & FF & $\eta(\%)$ \\
\hline PMII & Pt/ITO & 1.3 & 0.68 & 0.33 & 0.29 \\
\hline MWNT-PTh/PMII & $\mathrm{Pt} / \mathrm{ITO}$ & 10.2 & 0.73 & 0.64 & 4.76 \\
\hline PMII & ITO & 1.0 & 0.49 & 0.27 & 0.13 \\
\hline MWNT-PTh/PMII & ITO & 7.6 & 0.62 & 0.60 & 2.83 \\
\hline Liquid electrolyte $^{\mathrm{b}}$ & $\mathrm{Pt} / \mathrm{ITO}$ & 15.4 & 0.70 & 0.73 & 7.86 \\
\hline
\end{tabular}

${ }^{a}$ Conditions: sealed cells; dye: N719; coadsorbate: DCA $40 \mathrm{mM}$; photoelectrode: $\mathrm{TiO}_{2}\left(15 \mu \mathrm{m}\right.$ thickness and $\left.0.25 \mathrm{~cm}^{2}\right)$; irradiated light: AM $1.5 \mathrm{solar}$ light $\left(100 \mathrm{~mW} \mathrm{~cm}^{-2}\right) . J_{\mathrm{sc}}$ : short-circuit photocurrent density; $V_{\mathrm{oc}}$ : open-circuit photovoltage; FF: fill factor; $\eta$ : total power conversion efficiency.

${ }^{\mathrm{b}}$ Liquid electrolyte was composed of $0.6 \mathrm{M}$ dimethylpropyl-imidazolium iodide (DMPII), $0.05 \mathrm{M} \mathrm{I}_{2}$, and $0.1 \mathrm{M}$ LiI in acetonitrile.

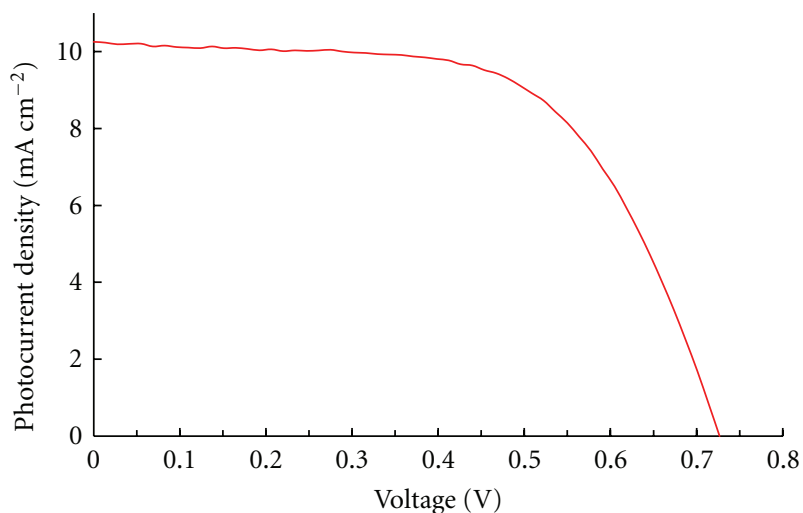

FIGURE 3: Photocurrent voltage characteristics of DSCs with MWNT-PTh/PMII composite electrolyte at AM 1.5 illuminations (light intensities: $100 \mathrm{~mW} \mathrm{~cm}^{-2}$ ).

voltmeter-constant current source system. The conductivity of the resulting MWNT-PTh composites at room temperature is $3.2 \mathrm{~S} \mathrm{~cm}^{-1}$, which is higher than that of the pristine PTh $\left(\sim 1.1 \times 10^{-4} \mathrm{~S} \mathrm{~cm}^{-1}\right)$, which is synthesized without MWNT, under the same conditions. The combination of PTh with MWNT has effectively increased the conductivity four orders of magnitude for the MWNT-PTh composites compared with the counterpart bulk PTh powders. A lower resistance is expected for MWNT-PTh/PMII composites electrolyte compared to that of bare PMII.

The photovoltaic performances of the DSCs under AM $1.5 \mathrm{G}$ simulated solar light at a light intensity of $100 \mathrm{~mW} \mathrm{~cm}^{-2}$ using MWNT-PTh/PMII composite electrolyte and using bare PMII as electrolyte are shown in Table 1. The cell efficiency of MWNT-PTh/PMII device is $4.76 \%$, which is remarkably higher than that of bare PMII device $(0.29 \%)$. The low device efficiency of bare PMII device is due to significant decrease in both $J_{\mathrm{sc}}$ and FF. The presence of PTh-MWNT facilitates electron transfer from counterelectrode to $\mathrm{I}_{3}{ }^{-}$ions in MWNT-PTh/PMII composite device. Recently, Lee et al. reported, based on electrochemical impedance spectroscopy (EIS) analysis, that the presence of carbon materials in IL facilitates electron transfer from counterelectrode to $\mathrm{I}_{3}^{-}$, which enables the $\mathrm{I}^{-} / \mathrm{I}_{3}^{-}$redox couple to work more efficiently than they would in the absence of carbon materials [25]. An analogous explanation is also

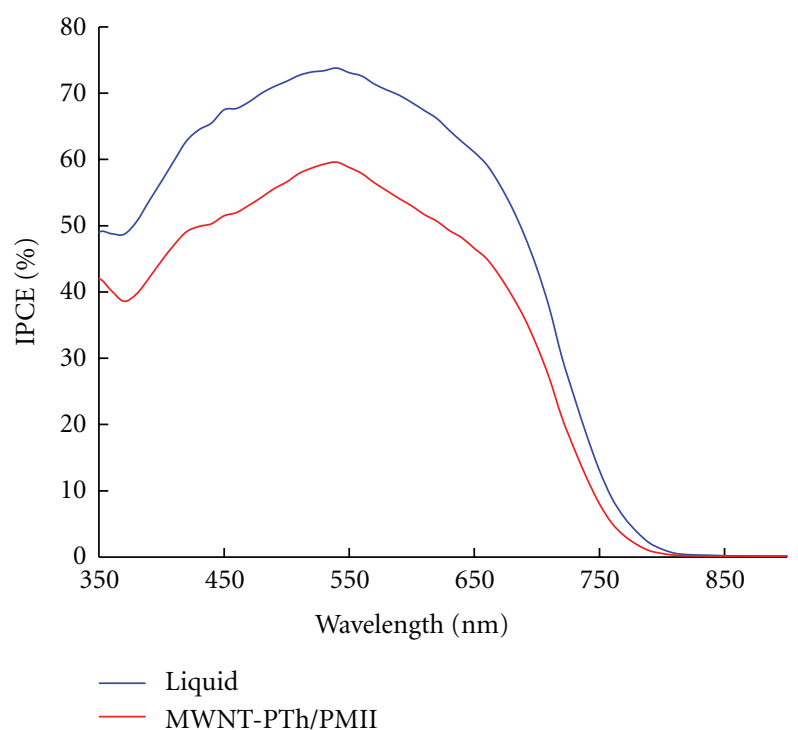

FIGURE 4: Photocurrent action spectra of the DSCs with MWNTPTh/PMII composite electrolyte and with liquid electrolyte. The incident photon-to-current conversion efficiency is plotted as a function of wavelength. A sandwich-type sealed cell configuration was used to measure this spectrum.

assumed for the MWNT-PTh/PMII composite electrolyte systems as well.

Figure 3 shows a photocurrent density-voltage curve of a sealed solar cell based on MWNT-PTh/PMII under AM 1.5 G simulated solar light at a light intensity of $100 \mathrm{~mW} \mathrm{~cm}^{-2}$. The MWNT-PTh/PMII electrolyte containing solar cell showed a photocurrent density of $10.2 \mathrm{~mA} \mathrm{~cm}^{-2}$, an open-circuit potential of $0.73 \mathrm{~V}$, and a fill factor of 0.64 , corresponding to an overall conversion efficiency $(\eta)$ of $4.76 \%$. In the same experimental condition, liquid electrolyte device shows an overall conversion efficiency $(\eta)$ of $7.86 \%$ with a high photocurrent density of $15.4 \mathrm{~mA} \mathrm{~cm}^{-2}$ (Table 1). Figure 4 shows the monochromatic incident photon to current conversion efficiency (IPCE) for DSCs based on MWNT-PTh/PMII composite and liquid electrolytes. Liquid-electrolyte-based device shows the maximum IPCE of $74 \%$ at $540 \mathrm{~nm}$, while the MWNT-PTh/PMII device shows only 59\% IPCE at $540 \mathrm{~nm}$. Inefficient charge transport properties in the composite electrolyte may be responsible for the low 
conversion efficiency in the MWNT-PTh/PMII-electrolytebased device. Further study will target the development of a high-performance quasi solid-state solar cell through improvement of charge transport properties in the composite electrolyte and also the catalytic activity of the electrolyte for electrochemical reduction of $\mathrm{I}_{3}^{-}$ions.

\section{Conclusion}

A $4.76 \%$ of light-to-electricity conversion efficiency of the quasi solid-state DSCs is obtained using hybrid MWNTPTh/PMII composites electrolyte without the addition of iodine under the radiation of $100 \mathrm{~mW} \mathrm{~cm}^{-2}$ (AM1.5 full sunlight). The cell efficiency of the quasi solid-state DSCs incorporating highly conducting MWNT-PTh composite is one order higher than that of bare PMII device $(0.29 \%)$. It is assumed that the hybrid MWNT-PTh composite plays a key role in both charge transportation in the composite electrolyte and the catalytic activities for electrochemical reduction of $\mathrm{I}_{3}^{-}$.

\section{Acknowledgment}

The authors gratefully acknowledge the financial support from NPST program by King Saud University of project no. 10-NAN1021-02.

\section{References}

[1] B. O’Regan and M. Grätzel, "A low-cost, high-efficiency solar cell based on dye-sensitized colloidal $\mathrm{TiO}_{2}$ films," Nature, vol. 353, no. 6346, pp. 737-740, 1991.

[2] A. Hagfeld and M. Grätzel, "Light-induced redox reactions in nanocrystalline systems," Chemical Reviews, vol. 95, no. 1, pp. 49-68, 1995.

[3] M. Grätzel, "Conversion of sunlight to electric power by nanocrystalline dye-sensitized solar cells," Journal of Photochemistry and Photobiology A, vol. 164, no. 1-3, pp. 3-14, 2004.

[4] A. Hagfeldt and M. Grätzel, "Molecular photovoltaics," Accounts of Chemical Research, vol. 33, no. 5, pp. 269-277, 2000.

[5] M. K. Nazeeruddin, A. Kay, I. Rodicio et al., "Conversion of light to electricity by cis- $\mathrm{X}_{2}$ bis $\left(2,2^{\prime}\right.$-bipyridyl- $4,4^{\prime}$ dicarboxylate)ruthenium(II) charge-transfer sensitizers ( $\mathrm{X}=$ $\mathrm{Cl}^{-}, \mathrm{Br}^{-}, \mathrm{I}^{-}, \mathrm{CN}^{-}$, and $\left.\mathrm{SCN}^{-}\right)$on nanocrystalline $\mathrm{TiO}_{2}$ electrodes," Journal of the American Chemical Society, vol. 115, no. 14, pp. 6382-6390, 1993.

[6] K. Hara, H. Sugihara, Y. Tachibana et al., "Dye-sensitized nanocrystalline $\mathrm{TiO}_{2}$ solar cells based on ruthenium(II) phenanthroline complex photosensitizers," Langmuir, vol. 17, no. 19, pp. 5992-5999, 2001.

[7] J. Bandara and H. Weerasinghe, "Solid-state dye-sensitized solar cell with p-type $\mathrm{NiO}$ as a hole collector," Solar Energy Materials and Solar Cells, vol. 85, no. 3, pp. 385-390, 2005.

[8] G. K. R. Senadeera, T. Kitamura, Y. Wada, and S. Yanagida, "Enhanced photoresponses of polypyrrole on surface modified $\mathrm{TiO}_{2}$ with self-assembled monolayers," Journal of Photochemistry and Photobiology A, vol. 184, no. 1-2, pp. 234-239, 2006.

[9] J. E. Kroeze, N. Hirata, L. Schmidt-Mende et al., "Parameters influencing charge separation in solid-state dye-sensitized solar cells using novel hole conductors," Advanced Functional Materials, vol. 16, no. 14, pp. 1832-1838, 2006.

[10] T. Kato, A. Okazaki, and S. Hayase, "Latent gel electrolyte precursors for quasi-solid dye sensitized solar cells the comparison of nano-particle cross-linkers with polymer crosslinkers," Journal of Photochemistry and Photobiology A, vol. 179, no. 1-2, pp. 42-48, 2006.

[11] J. N. Freitas, C. Longo, A. F. Nogueira, and M.-A. de Paoli, "Solar module using dye-sensitized solar cells with a polymer electrolyte," Solar Energy Materials and Solar Cells, vol. 92, no. 9, pp. 1110-1114, 2008.

[12] J. Wu, Z. Lan, J. Lin et al., "A novel thermosetting gel electrolyte for stable quasi-solid-state dye-sensitized solar cells," Advanced Materials, vol. 19, no. 22, pp. 4006-4011, 2007.

[13] J. N. Freitas, A. F. Nogueira, and M.-A. de Paoli, "New insights into dye-sensitized solar cells with polymer electrolytes," Journal of Materials Chemistry, vol. 19, no. 30, pp. 5279-5294, 2009.

[14] B. I. Ito, J. N. De Freitas, M. A. De Paoli, and A. F. Nogueira, "Application of a composite polymer electrolyte based on montmorillonite in dye-sensitized solar cells," Journal of the Brazilian Chemical Society, vol. 19, no. 4, pp. 688-696, 2008.

[15] P. Wang, S. M. Zakeeruddin, P. Comte, I. Exnar, and M. Grätzel, "Gelation of ionic liquid-based electrolytes with silica nanoparticles for quasi-solid-state dye-sensitized solar cells," Journal of the American Chemical Society, vol. 125, no. 5, pp. 1166-1167, 2003.

[16] H. Usui, H. Matsui, N. Tanabe, and S. Yanagida, "Improved dye-sensitized solar cells using ionic nanocomposite gel electrolytes," Journal of Photochemistry and Photobiology A, vol. 164, no. 1-3, pp. 97-101, 2004.

[17] T. Katakabe, R. Kawano, and M. Watanabe, "Acceleration of redox diffusion and charge-transfer rates in an ionic liquid with nanoparticle addition," Electrochemical and Solid-State Letters, vol. 10, no. 6, pp. F23-F25, 2007.

[18] K. M. Lee, P. Y. Chen, C. P. Lee, and K. C. Ho, "Binary roomtemperature ionic liquids based electrolytes solidified with $\mathrm{SiO}_{2}$ nanoparticles for dye-sensitized solar cells," Journal of Power Sources, vol. 190, no. 2, pp. 573-577, 2009.

[19] C. P. Lee, K. M. Lee, P. Y. Chen, and K. C. Ho, "On the addition of conducting ceramic nanoparticles in solvent-free ionic liquid electrolyte for dye-sensitized solar cells," Solar Energy Materials and Solar Cells, vol. 93, no. 8, pp. 1411-1416, 2009.

[20] Z. Chen, H. Yang, X. Li, F. Li, T. Yi, and C. Huang, "Thermostable succinonitrile-based gel electrolyte for efficient, long-life dye-sensitized solar cells," Journal of Materials Chemistry, vol. 17, no. 16, pp. 1602-1607, 2007.

[21] W. U. Huynh, J. J. Dittmer, and A. P. Alivisatos, "Hybrid nanorod-polymer solar cells," Science, vol. 295, no. 5564, pp. 2425-2427, 2002.

[22] M. R. Karim, C. J. Lee, and M. S. Lee, "Synthesis and characterization of conducting polythiophene/carbon nanotubes composites," Journal of Polymer Science A, vol. 44, no. 18, pp. 5283-5290, 2006.

[23] M. R. Karim, C. J. Lee, Y.-T. Park, and M. S. Lee, "SWNTs coated by conducting polyaniline: synthesis and modified properties," Synthetic Metals, vol. 151, no. 2, pp. 131-135, 2005.

[24] M. Fu, Y. Zhu, R. Tan, and G. Shi, "Aligned polythiophene micro- and nanotubules," Advanced Materials, vol. 13, no. 24, pp. 1874-1877, 2001. 
[25] C.-P. Lee, P. Y. Chen, R. Vittal, and K.-C. Ho, "Iodine-free high efficient quasi solid-state dye-sensitized solar cell containing ionic liquid and polyaniline-loaded carbon black," Journal of Materials Chemistry, vol. 20, no. 12, pp. 2356-2361, 2010.

[26] C.-P. Lee, L.-Y. Lin, P.-Y. Chen, R. Vittal, and K.-C. Ho, "Allsolid-state dye-sensitized solar cells incorporating SWCNTs and crystal growth inhibitor," Journal of Materials Chemistry, vol. 20, no. 18, pp. 3619-3625, 2010.

[27] H. Wang, H. Li, B. Xue, Z. Wang, Q. Meng, and L. Chen, "Solid-state composite electrolyte Lil/3-hydroxypropionitrile/SiO ${ }_{2}$ for dye-sensitized solar cells," Journal of the American Chemical Society, vol. 127, no. 17, pp. 6394-6401, 2005.

[28] N. Ikeda, K. Teshima, and T. Miyasaka, "Conductive polymercarbon-imidazolium composite: a simple means for constructing solid-state dye-sensitized solar cells," Chemical Communications, no. 16, pp. 1733-1735, 2006.

[29] M. R. Karim, J. H. Yeum, M. S. Lee, and K. T. Lim, "Synthesis of conducting polythiophene composites with multi-walled carbon nanotube by the $\gamma$-radiolysis polymerization method," Materials Chemistry and Physics, vol. 112, no. 3, pp. 779-782, 2008.

[30] M. K. Nazeeruddin, P. Péchy, T. Renouard et al., "Engineering of efficient panchromatic sensitizers for nanocrystalline $\mathrm{TiO}_{2}$ based solar cells," Journal of the American Chemical Society, vol. 123, no. 8, pp. 1613-1624, 2001.

[31] M. Ikeda, N. Koide, L. Han, A. Sasahara, and H. Onishi, "Scanning tunneling microscopy study of black dye and deoxycholic acid adsorbed on a rutile $\mathrm{TiO}_{2}(110)$," Langmuir, vol. 24, no. 15, pp. 8056-8060, 2008.

[32] Z. S. Wang, Y. Cui, Y. Dan-oh, C. Kasada, A. Shinpo, and K. Hara, "Thiophene-functionalized coumarin dye for efficient dye-sensitized solar cells: electron lifetime improved by coadsorption of deoxycholic acid," Journal of Physical Chemistry C, vol. 111, no. 19, pp. 7224-7230, 2007.

[33] N. Papageorgiou, Y. Athanassov, M. Armand et al., "The performance and stability of ambient temperature molten salts for solar cell applications," Journal of the Electrochemical Society, vol. 143, no. 10, pp. 3099-3108, 1996.

[34] P. Wang, S. M. Zakeeruddin, J. E. Moser, R. H. Baker, and M. Grätzel, "A solvent-free, $\mathrm{SeCN}^{-} /(\mathrm{SeCN})_{3}{ }^{-}$based ionic liquid electrolyte for high-efficiency dye-sensitized nanocrystalline solar cells," Journal of the American Chemical Society, vol. 126, no. 23, pp. 7164-7165, 2004.

[35] R. Kawano, H. Matsui, C. Matsuyama et al., "High performance dye-sensitized solar cells using ionic liquids as their electrolytes," Journal of Photochemistry and Photobiology A, vol. 164, no. 1-3, pp. 87-92, 2004. 

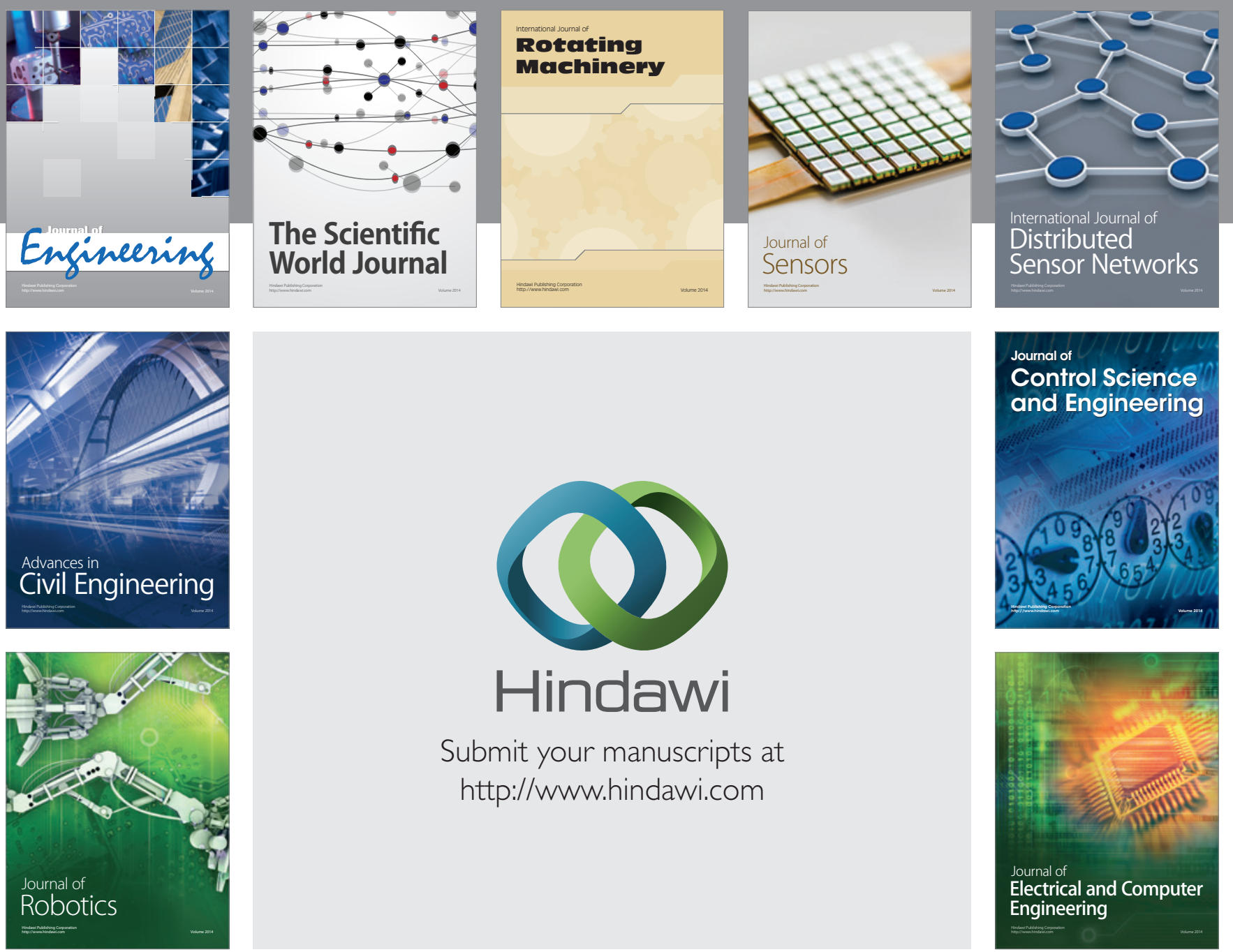

Submit your manuscripts at

http://www.hindawi.com
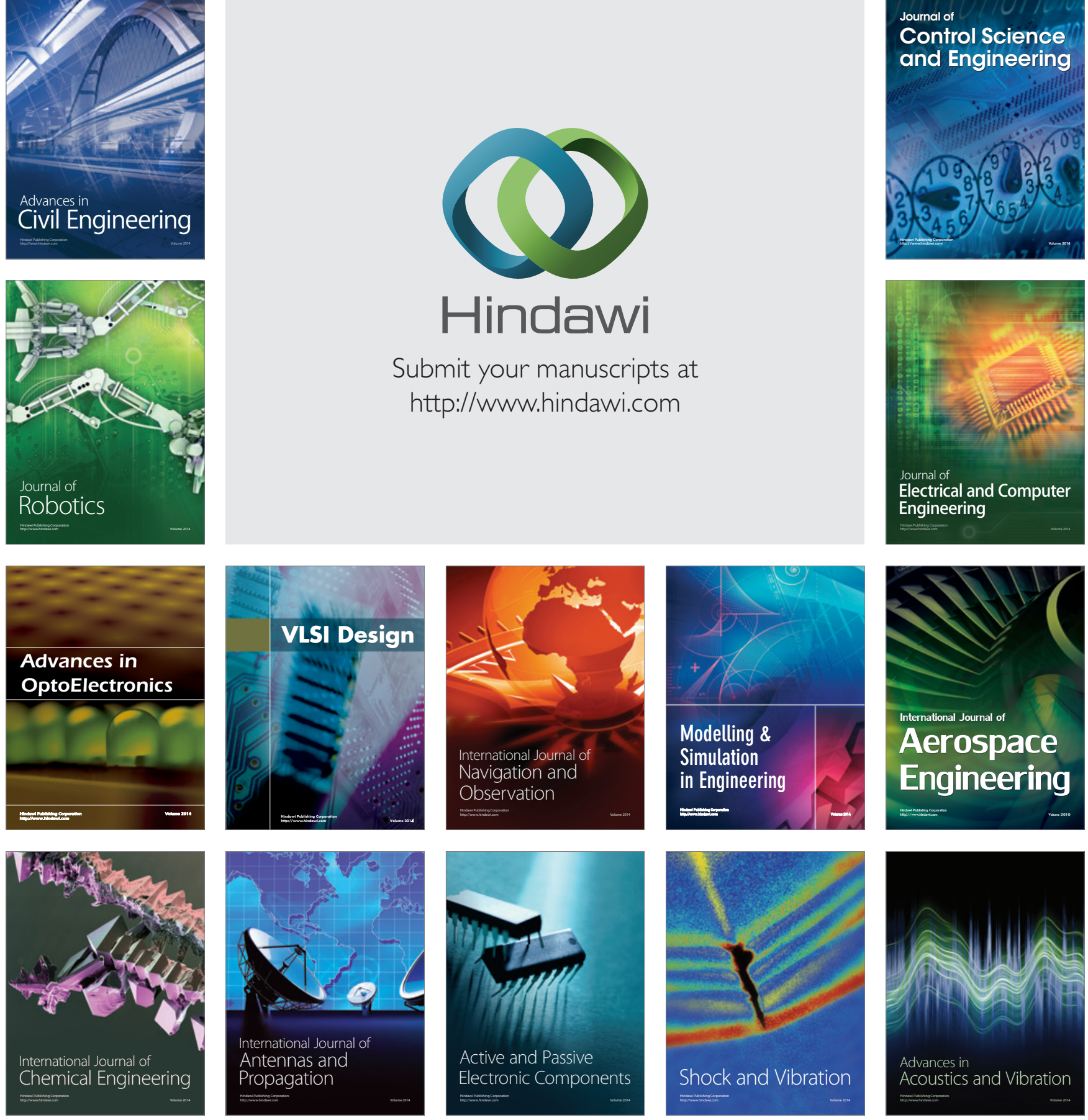